\title{
Pilomyxoid Astrocytoma: Case Report
}

\section{Astrocitoma pilomixoide: relato de caso}

\author{
Renato Pignatari ${ }^{1}$ Manoel Jacobsen Teixeira ${ }^{2}$ Eberval Gadelha Figueiredo ${ }^{2}$ \\ ${ }^{1}$ Faculdade de Medicina da Universidade de São Paulo, São Paulo, \\ SP, Brazil \\ 2 Division of Neurological Surgery, Faculdade de Medicina da \\ Universidade de São Paulo, São Paulo, SP, Brazil \\ Address for correspondence Renato Pignatari, MBBS, Faculdade de \\ Medicina da Universidade de São Paulo, Av. Dr. Arnaldo, \\ 455 - Cerqueira César, São Paulo, SP, 01246-903, Brazil \\ (e-mail: rp.pignatari@gmail.com).
}

Arq Bras Neurocir 2018;37:54-57.

\begin{abstract}
\section{Keywords}

- astrocytoma

- primary brain neoplasm

- hypothalamus

- neurosurgery

\section{Resumo}

The pilomyxoid astrocytoma (PMA) is a rare glioma recently described as a separate entity, which is generally located on the hypothalamic area. The PMA was previously described as pilocytic astrocytoma (PA) due to similarities shared between them. Recent studies provided a deeper understanding of PMA, setting it as a separate entity, though PMA is still considered by many authors a variant of PA. The PMA is considered to be more aggressive than PA; however, further studies are necessary for a better comprehension of its behavior and, hence, for neurosurgeons and neurologists to get to a consensus about its management.

This study presents a 16-year-old female patient who looked for medical assistance complaining of headaches of over 6 months and vomiting for 2 weeks prior to the visit to the doctor. She presented no other symptoms. The physical examination displayed only bilateral papilledema. The magnetic resonance imaging (MRI) scans showed an intraventricular and thalamic lesion composed of solid and cystic material associated with peritumoral edema. The patient underwent ventriculoperitoneal shunt and subtotal resection of the lesion. The histological and immunohistochemical studies showed typical features of PMA. The patient started adjuvant therapy with chemotherapy and radiosurgery. She has been asymptomatic for 9 months and has shown no signs of progression of the disease on the follow-up scans.

O astrocitoma pilomixoide (APM) é um raro glioma, recentemente descrito como uma entidade separada, que geralmente se localiza na região hipotalâmica. Anteriormente, o APM era descrito como astrocitoma pilocítico (AP) devido a características semeIhantes que ambos apresentam. Estudos recentes permitiram um melhor entendimento do APM, configurando-o como uma entidade separada, embora o APM ainda seja considerado por muitos autores uma variante do AP. O APM é considerado mais agressivo que o AP; no entanto, mais estudos são necessários para um melhor entendimento do comportamento do tumor e, consequentemente, para que neurocirurgiões e neurologistas cheguem a um consenso sobre sua terapêutica.

Este estudo apresenta uma paciente de 16 anos que procurou atendimento médico com queixas de dores de cabeça por mais de 6 meses e vômitos nas 2 semanas
\end{abstract}




\author{
Palavras-chave \\ - astrocitoma \\ - neoplasias encefálicas \\ - hipotálamo \\ - neurocirurgia
}

antecedentes à visita ao médico. Outros sintomas não eram apresentados. O exame físico revelou apenas papiledema bilateral. As imagens de ressonância magnética mostraram uma lesão intraventricular e hipotalâmica de componentes sólido e cístico associados a edema peritumoral. A paciente foi submetida a derivação ventriculoperitoneal e a ressecção subtotal da lesão. Os estudos histológico e imunohistoquímico demonstraram características típicas de APM. A paciente iniciou terapia adjuvante com quimioterapia e radiocirurgia. A paciente está em acompanhamento por 9 meses e, até o momento, manteve-se assintomática e não houve sinais de progressão da doença nos exames de imagem.

\section{Introduction}

The pilomyxoid astrocytoma (PMA) is a rare tumor of the central nervous system with higher prevalence among young children and generally located on the hypothalamic area. It was first described as a separate entity in $1999 .{ }^{1}$ Previously, the PMA was classified as a pilocytic astrocytoma (PA) due to several features that they share. The histological differentiation between PMA and PA provided a further analysis of the PMA's behavior and, consequently, a better development of its management, though neurosurgeons and neurologists still have not reached a consensus. Though considered different entities, many authors describe the PMA as a variant of PA, in which it is believed that the PMA is part of the natural process of maturation of the PA. ${ }^{2-4}$ This study presents a case of a 16 -yearold female patient with the diagnosis of PMA.

\section{Case Report}

A 16-year-old female patient, previously healthy, presented to the medical service complaining of nausea and vomiting for a period of over 2 weeks. Patient had a history of headaches, which started 6 months prior to her current presentation and were progressively worsening. She denied having focal neuro- logical deficits or any other symptoms. The neurological examination revealed only bilateral papilledema.

Magnetic Resonance imaging (MRI) of the head displayed a well-circumscribed lesion of solid and cystic components at the intraventricular and thalamic regions. There was also a peritumoral edema associated with mass effect and hydrocephalus (-Fig. 1).

The patient underwent ventriculoperitoneal shunt to treat the hydrocephalus and intracranial hypertension. After 2 weeks, she underwent another surgical procedure through frontal craniotomy with transcallosal approach, which resulted in subtotal resection of the lesion.

The histological examination identified a glial neoplasm composed of a monomorphic population of cells with oval nuclei and elongated cytoplasmic processes in a myxoid background. No mitotic figures or atypical cells were found. There was no evidence of Rosenthal fibers or eosinophilic granular bodies- which is typical in cases of PMA. The immunohistochemical analysis was positive for S100 protein, glial fibrillary acidic protein (GFAP), P53, integrase interactor 1 (INI-1) and was strongly positive for ki67, ranging from $80-90 \%$. The synaptophysin stain was inconclusive and the epithelial membrane antigen (EMA) study was negative.

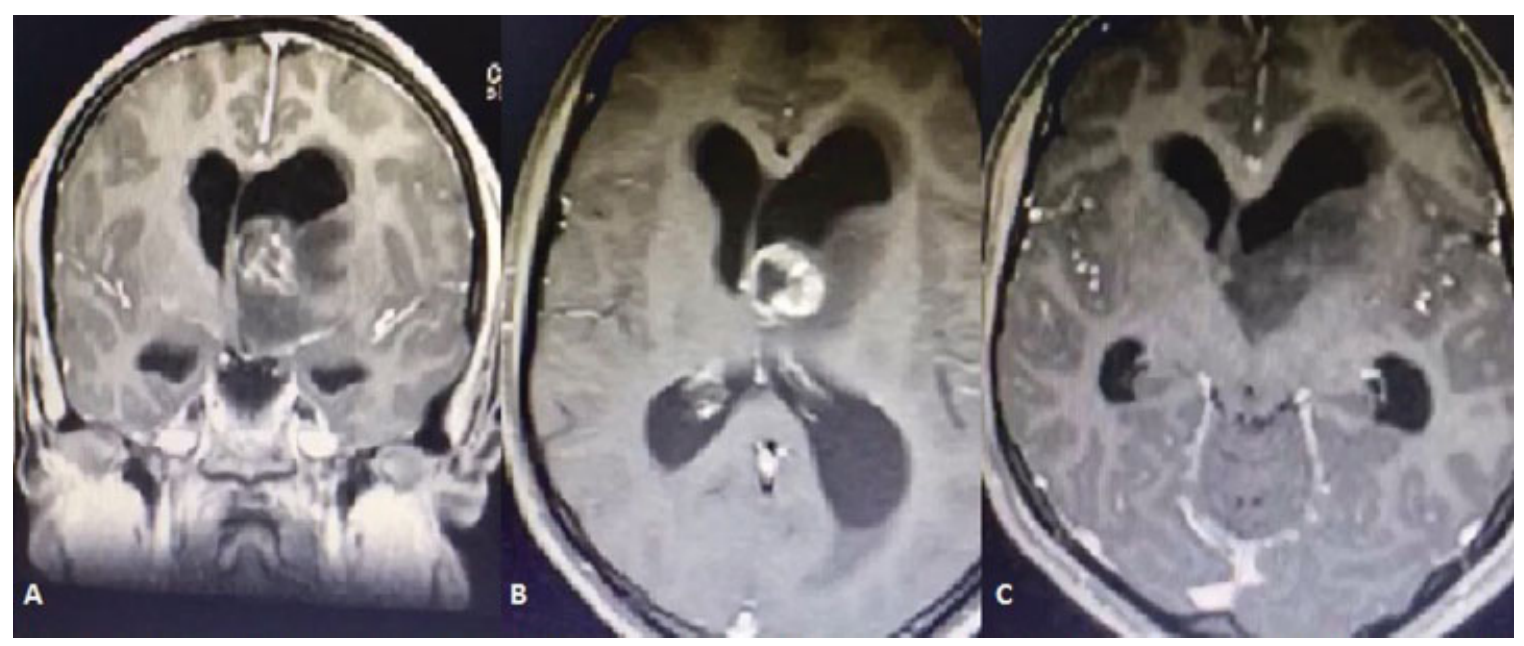

Fig. 1 (a) Coronal T1-weighted magnetic resonance imaging (MRI) demonstrating a well-circumscribed periventricular lesion, mildly enhanced. (b and c). Axial T1-weighted MRI revealing periventricular and hypothalamic lesion, mildly enhanced. On all scans, peritumoral edema, mass effect and signs of hydrocephalus can be seen. 
After the surgery, the patient started chemotherapy with temozolomide as adjuvant therapy associated with radiosurgery. The patient has been in follow-up for 9 months until the present date, and she has been asymptomatic so far. The MRI scan has shown no signs of progressions of the remaining lesion.

\section{Discussion}

The PMA is a rare tumor of the central nervous system first described in $1999 .^{1}$ Previously, due to some of its characteristics, the PMA was classified as pilocytic astrocytoma (PA). However, recent studies differentiated them, setting PMA and PA as two distinct entities. Still, some authors consider PMA a variant of PA, accounting PMA as part of a natural process of maturation of $\mathrm{PA} .^{2-4}$

The PMA represents $10 \%$ of tumors previously diagnosed as PA; PMA is more prevalent in the hypothalamus, while PA is the most common fossa posterior tumor during infancy. ${ }^{3}$ On average, PMA is diagnosed by the age of 18 months, and PA by the age of 58 months, both being considered childhood tumors. $^{5}$

Typical PMA histological characteristics consist of piloid monomorphous cells in a myxoid background, often without Rosenthal fibers and eosinophilic granular bodies. ${ }^{1,2,4-6}$ The tumor cells are generally arranged around vessels making a pattern that resembles pseudorosettes. ${ }^{1,2,4-6}$ By contrast, PA often presents eosinophilic granular bodies and Rosenthal fibers associates with dense cellular areas alternating loose and cystic regions. ${ }^{1,4}$

The clinical manifestations of PMA and PA can also distinguish these two tumors. When compared with PA, PMA has shown a more aggressive behavior, being responsible for higher rates of cerebrospinal fluid dissemination, shorter progression-free survival and shorter overall survival. 1,2,5,7

Imaging findings describe PMA as a well-circumscribed lesion, with solid and cystic components, often located on the hypothalamus. ${ }^{2,3,8}$ The lesions are generally isointense on T1-weighted MRI images and hyperintense on T2-weighted ones. ${ }^{2,8}$ Evidence of necrosis is rare and occasionally signs of hydrocephalus, mass effect and peritumoral edema may be seen. ${ }^{2,3,8}$ Several of these characteristics are shared with PA findings and therefore, there are no radiographic features that can reliably distinguish these two entities. ${ }^{2,8}$

Though recently PMA has been further studied, its behavior is still a matter of debate. The previous World Health Organization (WHO) classification for tumors of the central nervous system classified the PMA as a grade II tumor, while PA is reported as grade I. ${ }^{9}$ The latest classification, released in 2016, suppressed the grade of PMA due to the lack of elucidation of PMA's behavior and of its relation to PA. In this last classification, PA remained classified as grade I, owing it to its indolent course. ${ }^{9}$

This lack of consensus regarding PMA's clinical course is reflected in the controversy in its management. Surgical resection is the mainstay treatment for low-grade astrocytomas. ${ }^{2,5}$ Depending on the location of the lesion, gross total resection (GTR) is indicated, as it is the best predictor of favorable outcomes. ${ }^{2}$ Surgery is not an option when it cannot be performed without aggravating or creating neurological deficit. ${ }^{10}$ Granted that PMA is mainly located on the hypothalamus, GTR is often not possible, leading to partial or subtotal resection of the tumor. ${ }^{5,7}$ Ventriculoperitoneal shunt is often performed, given the findings of mass effect and symptoms of intracranial hypertension. ${ }^{10}$

Adjuvant therapy is administered in the cases in which surgery is not an option of treatment, GTR is not possible or in cases of recurrence of the tumor. ${ }^{2}$ The main types of adjuvant therapy are chemotherapy, radiotherapy and radiosurgery. Chemotherapy is the usual choice of treatment, once PMA is more frequent during infancy and radiosurgery and radiotherapy are not indicated in early ages. ${ }^{7,10}$

Surgery is considered the choice of treatment for recently diagnosed circumscribed gliomas in which the rates of progression of disease are lower; however, PMA shows a higher rate of recurrence after surgery when compared with PA. ${ }^{5,6,10}$ Regarding relapsed tumors, a combined therapy consisting of surgery, chemotherapy and radiotherapy displayed more favorable outcomes. $^{5}$

This case report shows a 16-year-old female patient with the diagnosis of PMA who underwent subtotal resection of the tumor associated with adjuvant therapy with temozolomide and radiosurgery, as the patient is old enough to accept radiation. Nine months after the treatment, no progression of the disease was seen on MRI and the patient is asymptomatic.

\section{Conclusion}

Pilomyxoid astrocytoma is a rare central nervous system tumor recently described and with few reports thus far, which leads neurosurgeons and neurologists to a lack of understanding of the behavior of the tumor and, consequently, its management. The authors report a case of a 16-year-old female patient with PMA who underwent subtotal resection of the tumor associated with chemotherapy and radiosurgery and has shown no signs of progression of the disease on a 9-month follow-up.

Pilomyxoid astrocytoma has been described as a more aggressive tumor of the infancy when compared with PA, and its treatment remains controversial. Further studies are necessary for a better understanding of this tumor's clinical course and hence, for an improvement on the types of treatment.

\section{Conflicts of Interest}

Authors declare no conflicts of interest.

\section{References}

1 Tihan T, Fisher PG, Kepner JL, et al. Pediatric astrocytomas with monomorphous pilomyxoid features and a less favorable outcome. J Neuropathol Exp Neurol 1999;58(10):1061-1068

2 Komotar RJ, Mocco J, Jones JE, et al. Pilomyxoid astrocytoma: diagnosis, prognosis, and management. Neurosurg Focus 2005;18 (6A):E7

3 Bhargava D, Sinha P, Chumas P, et al. Occurrence and distribution of pilomyxoid astrocytoma. Br J Neurosurg 2013;27(04):413-418 
4 Ceppa EP, Bouffet E, Griebel R, Robinson C, Tihan T. The pilomyxoid astrocytoma and its relationship to pilocytic astrocytoma: report of a case and a critical review of the entity. J Neurooncol 2007;81 (02):191-196

5 Komotar RJ, Burger PC, Carson BS, et al. Pilocytic and pilomyxoid hypothalamic/chiasmatic astrocytomas. Neurosurgery 2004;54 (01):72-79, discussion 79-80

6 Komotar RJ, Mocco J, Zacharia BE, et al. Astrocytoma with pilomyxoid features presenting in an adult. Neuropathology 2006;26(01):89-93

7 Matsuzaki K, Kageji T, Watanabe H, Hirose T, Nagahiro S. Pilomyxoid astrocytoma of the cervical spinal cord successfully treated with chemotherapy: case report. Neurol Med Chir (Tokyo) 2010;50(10):939-942

8 Alkonyi B, Nowak J, Gnekow AK, Pietsch T, Warmuth-Metz M. Differential imaging characteristics and dissemination potential of pilomyxoid astrocytomas versus pilocytic astrocytomas. Neuroradiology 2015;57(06):625-638

9 Louis DN, Perry A, Reifenberger G, et al. The 2016 World Health Organization Classification of Tumors of the Central Nervous System: a summary. Acta Neuropathol 2016;131(06):803-820

10 Tjahjadi M, Arifin MZ, Sobana M, et al. Cystic pilomyxoid astrocytoma on suprasellar region in 7-year-old girl: Treatment and strategy. Asian J Neurosurg 2015;10(02):154-157 